\title{
Effects of Intercropping on the Performance of Maize and Cowpeas in Botswana
}

\author{
Gabatshele.M. Legwaila", Teko. K. Marokane, Witness Moje remane \\ Department of Crop Science and Production, Botswana College of A griculture, Private Bag, 0027, Gaborone, Botswana
}

\begin{abstract}
A field experiment was conducted at Botswana College of Agriculture garden to investigate the effects intercropping maize and cowpeas on the performance of maize and cowpeas. The treatments were sole maize crop, sole cowpea crop, intercrop 1 (spacing of $40 \mathrm{~cm}$ between of maize and cowpea) and intercrop 2 (spacing of $30 \mathrm{~cm}$ between maize and cowpea served as treatments. The experiment was monitored fro $m$ November to March. The results show that only maize dry matter was significantly reduced by intercropping. Intercropping reduced the number cowpea flowers perp lant but had no significant effect in the number of seeds per pod and weight of seeds. Cowpea dry matter weight was significantly reduced by intercropping. Planting pattern significantly affected the number of cowpea flowers, nu mber of pods and dry matter weight. Appropriate spacing/ planting pattern should be considered when intercropping cereal and legume.
\end{abstract}

Keywords Intercropping, Cowpeas Maize Performance, Yield

\section{Introduction}

Farmers practice different cropping systems to increase productivity and sustainability[1]. Intercropping is the simultaneous growing of two or more crops in the same field [2] and is a cropping system that has long been used for a long-time in tropical areas. It increases total productivity per unit area through maximum utilization of land, labour and growth resources $[3,4,5]$. Yields of intercropping are often higher than in sole cropping systems[6] mainly due to resources such as water, light and nutrients that can be utilised more effectively than in sole cropping systems [7].

Cereal-legume intercropping plays an important role in subsistence food production in both developed and developing countries, especially in situations of limited water resources [8]. Intercropping of cereal and legume crops helps maintain and imp rove soil fertility [9] and plays an important role in subsistence food production in developing countries[8] because farmers cannot afford inorganic fertilizers. . Legumes fix atmospheric nitrogen, which may be utilized by the host plant or may be excreted from the nodules into the soil and be used by other plants growing nearby[10].

Legumes can also transfer fixed $\mathrm{N}$ to intercropped cereals during their joint growing period and this $\mathrm{N}$ is an important resource for the cereals[11].

The use of intercropping by smallholder farmers is a

* Corresponding author:

lgabatshele@y ahoo.com (Gabatshele. M. Legwaila)

Published online at http://journal.sapub.org/ijaf

Copyright (C) 2012 Scientific \& Academic Publishing. All Rights Reserved common practice[12] that dates back to ancient time[13] in the tropics[14] and rain-fed areas worldwide[15]. Declining crop yields in the smallholder farmers in dryland cropping systems in Botswana present the need to develop a more sustainable cropping system. Due to high costs of inorganic fertilizers, the majo rity of smallholder farmers in Botswana grow maize and sorghum in soils deficient in nitrogen, phosphorus and potassium. To maintain productivity in smallholder cropping systems in southern Africa, the use of inorganic fertilizers in combination with available organic fertilizers such as kraal manure, tree litter, herbaceous legume plant residues and compost is required [16].

Intercropping legumes with non-legume in Botswana can be a principal means of intensifying crop production both spatially and temporally to improve crop yields for smallholder farmers. Legume intercrops are a potential source of plant nutrients that compliment/supplement inorganic fertilizers[17]. Legume intercrops have several socioeconomic[18], and biological and ecological[19, 20, 21, 22, 23] advantages compared to sole cropping for small-holder farmers [24]. In addition, certain legumes crops provide food to humans and livestock[17]. There are several intercrop arrangements which may include row intercropping worldwide. The objective of the present study was to determine the effect of intercropping and planting patterns on the performance of maize and cowpeas in semi-arid Botswana.

\section{Materials and Methods}

The field study was conducted during the 2006/2007 
cropping season (November to April) at Botswana College of Agriculture (BCA) garden. BCA is located at Sebele (Latitude: 24 34'S; Longitude: 25 54'E: Altitude: 994m) approximately $10 \mathrm{~km}$ north of the Gaborone City along the north to south highway. The study site is characterised by a semi-arid climate with mean annual rainfall of $538 \mathrm{~mm}$. Most of the rain fall in the summer starting from late October and continues to March/April. The study area is characterised by shallow sandy loam soils and Acacia trees.

Maize (Zea mays L.) and Tswana cowpea (Vigna unguiculata (L.) Walp) are two crops used in the present study. The experiment had four treatments, sole maize crop, sole cowpea crop, intercrop 1 (spacing of $40 \mathrm{~cm}$ between rows of maize and cowpeas) and intercrop 2 (spacing of $30 \mathrm{~cm}$ between rows of maize and cowpeas). The experimental design used was a randomized comp lete block design and the experimental plots were replicated four times.

The experimental field was prepared by ploughing the soil to a depth of $30 \mathrm{~cm}$ and harrowing. The size of the plot per treatment was $3 \times 3\left(9 \mathrm{~m}^{2}\right)$ with $50 \mathrm{~cm}$ paths separating adjacent plots and blocks. In the sole maize crop treatment, three maize seeds were sown per hole at a depth of $5 \mathrm{~cm}$ and later thinned to one seedling/hole at a spacing of $90 \times 30 \mathrm{~cm}$. In the sole cowpea crop treatment, two seeds were sown per hill at depth of $5 \mathrm{~cm}$ and later thinned to one at $30 \times 15 \mathrm{~cm}$ spacing. In the intercrop 1 treatment, there were four rows of maize planted at spacing of $80 \times 40 \mathrm{~cm}$ and between every two rows; a row of cowpea was placed at $40 \mathrm{~cm}$ from maize rows and $20 \mathrm{~cm}$ between plants. In the intercrop 2 treatment, five rows of cowpeas were planted at a spacing of $60 \times 30 \mathrm{~cm}$ and a row of maize placed at a spacing of $30 \mathrm{~cm}$ from cowpeas and $20 \mathrm{~cm}$ between plants. Watering was also done when crops showed water stress and weeding was done manually when necessary. No fertiliser or insecticide application was made. Specific maize and cowpea plants were tagged for measurements and harvested at end of the experiment to determine dry matter (DM) weight.

The following parameters were assessed: number of flowers, nu mber of pods, number of cobs perp lant, weight of 100 seeds and DM weight at the end the experiment. The DM weight or biomass was determined by weighing after oven drying the plant material at $70^{\circ} \mathrm{C}$ for 3 days. All the data collected were statistically analysed using the analysis of variance (ANOVA) procedure using SAS[25] and Duncan Multiple Range Test was used to separate the means.

\section{Results and Discussion}

The results on the effect of intercropping on measured maize parameters are shown in Table 1.

The sole crop produced significantly more DM weight than maize intercropped with cowpeas. The maize DM weight was not affected by planting patterns used in the two intercropping systems. Competition among mixtures is thought to be a major factor affecting yield as compared with sole cropping of cereals[26]. The high maize DM weight observed in the sole maize crop could be attributed to high plant density and lack of competition for resources such as light, nutrients and water. Factors that affect competition in intercropping systems were not determined in the present study. However, differences in the depth of roots, lateral root spread and root densities are some of the factors that affect competition between the component crops in an intercropping system for nutrients[27]. Previous studies reported yield reduction in cowpea and maize in maize-co wpea intercrops [28] due lower plant densities.

Table 1. Effect of intercropping on the number maize cobs per plant, weight of 100 seeds and dry matter weight

\begin{tabular}{|c|c|c|c|}
\hline Treatment & No of cobs plant $^{-1}$ & Weight of 100 seeds $(\mathrm{g})$ & DM $(\mathrm{g})$ \\
\hline Sole maize (control) & $2.00 \mathrm{a}$ & $24.33 \mathrm{a}$ & $197.33 \mathrm{a}$ \\
\hline Intercrop 1 & $1.66 \mathrm{a}$ & $23.00 \mathrm{a}$ & $169.33 \mathrm{~b}$ \\
\hline Intercrop 2 & $1.66 \mathrm{a}$ & $21.00 \mathrm{a}$ & $165.66 \mathrm{~b}$ \\
\hline SEM & 0.30 & 1.30 & 6.55 \\
\hline CV & 29.64 & 9.877 & 6.494 \\
\hline LSD & 1.195 & 5.124 & 26.117 \\
\hline
\end{tabular}

Mean values followed by the same letter are not significantly different from each other $(\mathrm{P}>0.05)$

Table 2. Effect of intercropping on flowers, number of pods per plant, number of seeds per pod, weight of 100 seeds and DM of cowpea

\begin{tabular}{|c|c|c|c|c|c|}
\hline Treatment & $\begin{array}{c}\text { No of flowers plant } \\
\text { /plant }\end{array}$ & No of pods plant ${ }^{-1}$ & No of seeds/pods & Wt of 100 seeds $(\mathrm{g})$ & DM $(\mathrm{g})$ \\
\hline Sole cowpea & $28.25 \mathrm{a}$ & $24.75 \mathrm{a}$ & $14.00 \mathrm{a}$ & $15.75 \mathrm{a}$ & $62.50 \mathrm{a}$ \\
\hline Intercrop 1 & $24.00 \mathrm{~b}$ & $23.25 \mathrm{a}$ & $13.00 \mathrm{~b}$ & $16.00 \mathrm{a}$ & $73.50 \mathrm{~b}$ \\
\hline Intercrop 2 & $19.75 \mathrm{c}$ & $18.50 \mathrm{~b}$ & $13.75 \mathrm{a}$ & $15.75 \mathrm{a}$ & $51.25 \mathrm{c}$ \\
\hline SEM & 0.73 & 1.27 & 0.14 & 0.43 & 2.47 \\
\hline CV & 6.093 & 11.48 & 2.12 & 5.47 & 7.92 \\
\hline LSD & 2.53 & 4.40 & 0.449 & 1.498 & 8.55 \\
\hline
\end{tabular}

Mean values followed by the same letter are not significantly different $(\mathrm{P}>0.05)$ 
The results of the present study show that the number of maize plant cobs and weight of seeds were not affected by intercropping systems. Similarly there was no significant difference in the two variables between planting patterns (intercrop 1 and 2). This is consistent with results of a study conducted by Agricultural Research Division [29] which reported that a sorghum-co wpea intercrops did not reduce or increase sorghum yield. Our results are also in agreement with Haizel [30], who worked with maize-cowpea, and Andrews [31] and Rees[32], who worked with sorghum-cow pea and Karikari[33] who worked with maize-bambara groundnut and sorghum-bambara groundnut intercrop systems.

The results of different parameters of cowpea in intercrops with maize are shown in Table 2. Sole cowpea produced significantly more flowers per plant than intercropped with maize. Maize is usually taller with a faster growing or more extensive root system; particularly a larger mass of fine roots and is competitive for soil nitrogen [34, 35]. The maize plants in the intercrops in the present study could have shadowed cowpeas reducing the amount of light required to stimulate flower production. These results also showed that the number of flowers per plant was significantly high in intercrop 2 than intercrop 1 probably due to differences in plant density between the two planting patterns. There was no significant difference in the number of cowpea pods between sole cowpea crop and intercrop 1 (wider cowpea spacing). Cowpea plants in both the sole cowpea crop and intercrop 1 produced more pods that the intercrop 2. The narrow spacing in intercrop 2 resulted in high cowpea plant density and hence competition for growth resources. This is consistent with the findings of Ofori and Stern[18] and Alhaji [36] who observed reduction in cowpea yield due to high maize density in the intercropping system. Studies conducted by Agricultural Research Division[29] also reported that intercropping reduced the yield of cowpea.

The results on the effect of intercropping on flowers, number o fpods perplant, number of seeds perpod, weight of 100 seeds and DM of cowpea are shown Table 2

There was no significant difference in the number of seeds per pod between the sole cowpea and intercropping 2 . Intercrop 1 significantly reduced the number of cowpea seeds per pod when compared to the sole crop and intercrop 2. Higher grain yield under sole cowpea compared to intercropping were reported by Chemeda [24]. Competition for water, nutrients and shading are probably the two factors that reduced cowpea yield under high numbers of maize plants in Intercrop 1[37]. There were no significant differences in the weight of cowpea seeds between treatments. This is in agreement with Chakma et al. [38] who observed no significant difference in weight of 1000 seed weight in a popcorn-mungbean/cowpea intercropping system[39] found that mungbean intercropped with cotton produced seeds similar to those in sole crop of mungbean which is consistent with our findings.

Sole cowpea crop produced significantly lower DM weight than intercrop 1 . The sole cowpea crop grew and matured faster because of lack of competition for resources such as light, water and nutrients. This caused sole cowpea plants to lose some leaves before harvesting for DM weight analysis. The loss of some leaves in the field could have lowered DM weight in the sole cowpea crop. It was observed that intercropped cowpeas matured while still hold ing leaves and this could be because shading by maize prevented them from dry ing. Intercrop 1 gave more DM weight than sole been and intercrop 2. At the end of the study, cowpeas in the intercrop 1 where still hold ing their leaves. Co wpeas in the intercrop 2 produced the least DM probably due to competition for resources due to high plant density.

\section{Conclusions}

The majority of s mallholder farmers in Botswana practice intercropping between cerealcrops and legumes, however on the basis of these findings; it is clear that sole cropping performed better than all intercrops. There are benefits derived from intercropping systems such nitrogen fixation by legume which benefits cereal crops and assurance for some crops surviving in the event that there are calamities like drought, pests and diseases.

\section{ACKNOWLEDGEMENTS}

Teko K. Marokane was supported by the Ministry of Education Scholarship. We thank Botswana College of Agriculture for providing the study site and a laboratory for carrying out some analysis

\section{REFERENCES}

[1] H. Hauggaard-Nieson, P. Ambus and E. S. Jensen, 2001. Temporal and spatial distribution of roots and competition for nitrogen in pea-barley intercrops. A field studies employing ${ }^{23} \mathrm{P}$ techniques. Plant Soil 236:63-74

[2] F. O. Takim, 2012, Advantages of Maize-Cowpea intercropping over sole cropping through competition indices. J. Agric. Biod. Res., 1(4): 53-59.

[3] B. Marshal and R.W. Willy, 1983, Radiation interception and growth in an intercrop of Pearl millet/groundnut. Field crops Res., 7:141-160.

[4] M.A. Quayyum, A. Ahmed and A.K. Chowdhury, 1999, Crop weed competition in maize + black gram in sole and intercropping system. Bangladesh J. Agril. Res. 24(2): 249-254.

[5] P.Q. Craufard, 2000, Effect of plant density on the yield of sorghum-cowpea and pearl millet-cowpea intercrops in northern Nigeria. Exp. Agric. 36(3):379-395.

[6] A.S. Lithourgidis, I.B. Vasilakoglou, K.V. Dhima, C.A. Dordas and M.D. Yiakoulaki, 2006, Forage yield and quality of common vetch mixtures with oat and triticale in two seeding ratios. Field Crop Res. 99: 106-113. 
[7] L. Li, J.H. Sun, F.S. Zhang, X.L. Li, S.C. Yang and Z. Rengel, 2006, Wheat/maize or wheat/soybean strip intercropping I. Yield advantage and interspecific interactions on nutrients. Field Crop Res. 71:123-137.

[8] M. Dahmardeh, A. Ghanbari, B.A. Syahsar and M. Ramrodi, 2010, The role of intercropping maize (Zea mays L.) and Cowpea (Vigna unguiculata L.) on yield and soil chemical properties. African J. Agric. Res. 5(8):631-636.

[9] M. Tsubo and S. Walker, H.O. Ogindo, 2005, A simulation model of cereal-legume intercropping systems for semi-arid regions: 1. Model development. Field Crops Res. 93(1):10-22.

[10] R.W. Andrews, 1979, Intercropping, Its importance and research need I. Competition and yield advantages. Field Crops Abstr. 32: 1-10.

[11] Q.R. Shen and G.X. Chu, 2004, Bi-directional nitrogen transfer in an intercropping system of peanut with rice cultivated in aerobic soil. Biol. Fertil. Soils. 40(2):81-87.

[12] J. Ofuso-Amin and N.V. Limbani, 2007. Effect of intercropping on the growth and yield of cucumber and okra. Int. J. Agric. Biol. 9(4):594-597.

[13] M. Dahmardeh, A. Ghanbari, B. Syasar and M. Ramroudi M, 2009, Effect of intercropping maize with cowpea on green forage yields and quality evaluation. Asian J. Plant Sci. 8(3): $235-239$.

[14] P. Banik, P. Sasmal, K. Ghosal and D.K. Bagchi, 2000, Evaluation of mustard (Brassica compestris var. Toris) and legume intercropping under 1:1 and 2:1 row-replacement series system. J. Agro. Crop Sci. 185(1):9-14.

[15] D.K. Dhima, Lithourgidis A.A, I.B. Vasilakoqlou and C.A. Dordas, 2007, Competition indices of common vetch and cereals intercropping in two seeding ratio. Field Crops Res. 100(1-3):249-258.

[16] S.S. Snapp, P.L Mafongoya and S. Waddington, 1998, Organic matter technologies for integrated nutrient management in stallholder cropping systems of Southern Africa. Agric. Ecosyst. Eviron 71(1-2):185-200.

[17] P. Jeranyama, O.B. Hesterman, S.R. Waddington and R.R. Harwood, 2000, Relay-Intercropping of Sunnhemp and Cowpeas into a smallholder maize system in Zimbabwe. Agron. J. 92:239-244.

[18] F. Ofori and W.R. Stern, 1987, Cereal and legume intercropping systems. Advances in Agron. 41:41-90.

[19] H.A. Van Rheenen, D.E. Hasselbach and S.G.S. Muigai, 1981 The effect of growing beans together with maize on incidence of bean diseases and pests. Euro. J. Plant Path. 87(5):193-199.

[20] P.K. Aggarwal, D.P. Garrity, S.P. Liboon and R.A. Morris, 1992, Resource use and plant interactions in a rice-mungbean intercrop. Agron. J. 84(1):71-78.

[21] D.N. Exner and R.M. Cruse, 1993, Interseeded forage legume potential as winter ground cover, nitrogen source, and competitor. J. Prod. Agric. 6(2):226-231.

[22] G.E. Giller and G. Cadisch, 1995. Future benefits from biological nitrogen fixation: An ecological approach to agriculture. Plant Soil 174(1-2):255-277.
[23] F. Chemeda, 1996, Effect of bean and maize intercropping on bean common bacteria blight and rust diseases. Int. J. Pest Manag. 42(1):51-54.

[24] F. Chemeda, 1997, Effects of planting pattern, relative planting date and intra-row spacing on a haricot bean/maize intercrop. Afr. Crop Sci. J. 5(1):15-22

[25] SAS Institute (2001). SAS Procedure Guide. Version 8.2, SAS Inst., Cary, NC.

[26] P.A. Ndakidemi, 2006, Manipulating legume/cereal mixtures to optimize the above and below ground interactions in the traditional African cropping systems. Afri. J. Biotechnol. 5(25): 2526-2533.

[27] H. Eskandari and A. Ghanbari, 2009, Intercropping of Maize (Zea mays) and Cowpea (Vigna sinensis) as whole-crop forage: effect of different planting pattern on total dry matter production and maize forage quality. Not. Bot. Hort. Agrobot. Cluj 37(2):152-155.

[28] R.W. Willey and D.S.O. Osiru, 1972. Studies on mixtures of maize and beans with particular reference to plant population. J. Agric. Sci. Cambridge 79(3):517-529.

[29] Agriculture Research Division (1983/84). Annual report for the Division of Arable Crop Research 1979 - 84. A griculture Research Division, Ministry of Agriculture. Gaborone, Botswana.

[30] K.A. Haizel, 1974, Maize-cowpea intercropping study in Kumasi. Ghana J. Agric. Sci. 7:169-178.

[31] D.J. Andrews, 1972, Intercropping with sorghum in Nigeria. Exp. Agric. 8(2):139-150.

[32] D.J. Rees, 1986, Crop growth, development and yield in intercropping sorghum with cowpea in semi-arid conditions in Botswana. II. Exp. Agric. 22(2):169-177.

[33] S.K. Karikari, 2003, A decade of Bambara groundnut agronomic research at the Botswana College of A griculture. UNISWA J. of Agric. 12:24-28

[34] P.M. Carr, G. B. Martins, J. S. Caton and W. W. Poland, 1998. Forage and $\mathrm{N}$ yield of barley-pea and oat-pea intercrops. Agron. J. 90(1):79-84.

[35] K. Carruthers, B. Prithiviraj, O. Fe, D. Cloutler, R. C. Martin and D. L. Smith, 2000, Intercropping corn with soybean, lupin and forages: yield component responses. Eur. J.Agron. $12: 103-115$.

[36] I. H. Alhaji, 2008, Yield performance of some varieties under sole and intercropping with maize at Bauchi, Nigeria. Afric. Res. Rev. 2 (3):278-291.

[37] W. G. Lesoing and C. A. Francis, 1999, Strip intercropping effects on yield and yield components of corn, grain sorghum, and soybean. Agron. J. 91(5):807-813.

[38] R. Chakma, M.A. Aziz, A.K.M.M. Rahman, M.F. Khatun and M. Sultana, 2011, Intercropping popcorn with bushbean and pea at different planting systems in hill valley areas. J. Expt. Biosci. 2(2):35-38.

[39] M. B. Khan and A. Khaliq, 2004, Study of mungbean intercropping in cotton planted with different techniques. J. Res. (Science) 15(1):23-31. 